\title{
THE EFFECTIVENESS OF CORPORATE BRANDING STRATEGY IN MULTI-BUSINESS COMPANIES
}

\author{
Masume Hosseinzadeh Shahri \\ Faculty member of Business Management Department, \\ Alzahra University, IRAN \\ E-mail:mhshahri@alzahra.ac.ir
}

\begin{abstract}
Is your corporate branding strategy effective? This paper presents a triple-dimension model for the assessment of the effectiveness of corporate branding strategy as a strategic decision in an organization: multiple stakeholders' reliance, financial value and strategic position. The elements of the model are based on information obtained from literature review and structured interview with specialists in strategic management and marketing and some multi-business companies' managers. A questionnaire and confirmatory factor analysis (CFA) have been used to validate the measurement. Assessing the three dimensions (multiple stakeholders' reliance, financial value and strategic position) and integrating them into a scheme enable CEOs to understand whether their corporate branding strategy is effective.
\end{abstract}

Keywords: Multi-business companies, Effectiveness of corporate branding strategy, Multiple stakeholders' reliance, Financial value, Strategic position.

\section{INTRODUCTION AND PURPOSE OF THE STUDY}

Managers at the corporate level in multi-business firms that comprise different businesses have to coordinate the activities of multiple business units and consequently face a variety of strategic decisions that concern the overall corporation. One of these strategic decisions involves using corporate branding strategy. The purpose of this paper is to present a model that measures the effectiveness of corporate branding strategy. Strategic business units or SBUs are the autonomous subsidiaries, or separate organizational entities which usually have independent missions and objectives and are responsible for serving the particular demand of their segment. They have their own competitors and have a manager who is accountable for its operation, profit, investment and their own strategic development. The SBUs in multi-business companies create value through direct contact with customers and compete in their markets to generate revenues and profits. The corporate parent acts as an intermediary, influencing the decisions pursued by the businesses and standing between the businesses and those who provide capital for their use.Multi-business companies create value by influencing or parenting the businesses they own. The best parent companies create more value than any of their rivals would if they owned the same businesses (Goold, Campbell and Alexander, 1995).

There are various decisions to be made that are complex in nature, deeply affect the SBUs' performance and their core directions, and are strategically important. Strategic decisions, which are fundamental and developmental decisions as a part of the strategy process (Eisenhardt and Zbaracki, 1992), are some choices having chain consequences at the corporation causally, whose involvement level must be carefully controlled by corporate managers. They are difficult to define and also to assess in terms of performance; they interconnect with other decisions in the corporation and have high ambiguity and uncertainty (Wilson, 2003).

An important strategic decision is to build and maintain a favorable and strong brand (Sadler, 2003), which in turn will create a desirable external image for the company. Since SBUs have to operate in different industries and different markets, they want their own special brands and logos. The decision to apply a corporate brand, more generally called an organization brand (Aaker, 2004), must be made very carefully because the corporate brand is the identifier of a corporation and is used to support business unit communications. Consumers' perspective of the brand is transferred to other products that are marketed with the parent brand or corporate brand.

The corporate brand is a valuable asset that encompasses the vision, core values, image and actions of the corporation. The corporate brand increases its profitability and sales, reduces its costs and creates a unique position in the marketplace if it is based on a well-run promotion campaign following an effective corporate branding strategy (Hatch and Schultz, 2001; Aaker, 2004). Consequently, one crucial decision in multibusiness 
corporations is to determine the use of corporate branding strategy, and corporations should assess whether the selected strategy effectively meets the intended outcome our not.

\section{LITERATURE REVIEW}

\subsection{Corporate brand}

There is an important distinction between a corporate brand and a product brand. The product brand focuses on the product and the customer; while the marketing activity as a short, long, and tactical function handles it. In contrast, the corporate brand clearly focuses on the whole organization where the CEO has a crucial role and ultimate responsibility for its management. It considers multiple stakeholders as a strategic factor in the organization.

A corporate brand that has high complexity (Balmer, 2001) is a name, term, sign, symbol/ design or a combination of these elements, intended to identify and differentiate the company's products from those of the competitors in the minds of the subjects concerned (Ormeno, 2007). Essentially, it is about people, values, practices and processes (Balmer and Gray, 2003).

The corporate brand contributes not only to customer-based images of the organization but to the images formed and held by all its stakeholders which are include employees, customers, investors, suppliers, partners, regulators, special interests and local communities (Hatch and Schultz, 2001, 2008). The ability to use the vision and culture of a company as part of a unique selling proposition is brought by corporate branding to marketing (Hatch and Schultz, 2003). It also represents the agreement between the organization behind the brand and its multiple stakeholders (Balmer, 2004). Balmer suggested that corporate brands are underpinned by three elements: values, promises and behavior. Hatch and Schultz (2008) proposed successful corporate branding depended on the coherence between strategic vision, organizational culture, and stockholders' image.

\subsection{Branding strategy}

Branding strategy refers to the ways that firms mix and match their brand's name on their products (Laforet and Saunders, 1999); and a firm, through its products, presents itself to the world (Aaker, 2004; Olins, 1990). The degree of synergy between the corporate brand and the product brand depends on the brand architecture (Keller and Aaker, 1996; Varadarjan et al., 2006). The term "brand architecture" is sometimes used as a synonym of "branding strategy".

The concept of brand architecture, which explains how multiple product brands owned by a single company relate to one another, helps some people understand the relationship between a product and a corporate brand (Hatch and Schoultz, 2008). Several authors have studied branding strategy and have identified some strategies with different taxonomy, listed below:

a) Individual product branding and corporate branding.

b) Branded house and house of brand, including 'endorsed brands' and 'sub brands' (Aaker and Joachimstahler, 2000a).

c) Endorsement branding strategy (Laforet and Saunders, 1999); strong endorsement, token endorser and linked name (Aaker and Joachimsthaler, 2000a).

d) No endorsement, weak endorsement, medium endorsement and strong endorsement (Van Riel and Bruggen, 2002).

e) Muzellec and Lambkin (2009) identified two types of branding strategies: integration (ascending brand extension) and separation (descending brand extension). They proposed three types of corporate branding strategy within the brand architecture: trade name, business brand and holistic corporate brand.

f) Olins (1990) delineated three types of branding strategy that are along a continuum: monolithic strategy endorsed strategy and branded strategy.

g) Kapferer (2008) distinguished some strategies that respond to the market. They are structured along two axes: 1) the indicator of origin source effect reassurance, and 2) product differentiation, personalization and identification. These strategies consist of product brand, line brand, range brand, endorsing brand, source brand, umbrella brand, marker's mark, corporate endorsing brand, corporate source brand and corporate master brand.

Most companies employ mixed strategies but the paper briefly characterizes the two extremes: corporate brand strategy and product brand strategy.

\subsection{Corporate branding strategy}

Corporate branding strategy seeks to create unique identity and position for its products, services and ensures that both product and organization create value beyond that of their competitors (Ind, 1997). Corporate branding strategy can create added value for the corporation and implement its vision and create unique position in the 
marketplace. Also it can enable the corporation to bring further leverage to its tangible and non-tangible assets. It is a degree of endorsement by the parent brand that has two extremes: First, the uniformity model where both the corporate level and the business units are all positioned and profiled. Second, the variety model where business units are different from the corporate level (Van Riel and Bruggen, 2002).

Van Riel and Bruggen (2002) defined the corporate branding strategy as a systematically planned and implemented process of creating and maintaining a favorable reputation. They also said, its constituent elements by sending signals to stakeholders used the corporate brand. Some factors impact the crafting strategy of the corporate brand. Corporate strategy, business model, organizational culture, pace of innovation, added-value lever, resources and brand vision are factors that should be taken into account when choosing a branding strategy (Kapferer, 2008).

As already mentioned, there are some factors which affect successful branding strategy when the strategists of the organization select corporate brand strategy as a source of competitive advantage for parent and SBUs and for obtaining the other goals of the organization. Although corporate brand strategy can be beneficial, if it is not managed accurately and thoroughly, both parent and SBUs can suffer losses. Consequently, a holistic approach is necessary to appraise the effectiveness of the corporate brand strategy.

\section{CONCEPTUAL MODEL}

To assess the effectiveness of corporate branding strategy, this paper proposes three dimensions that can help the head office understand and manage their corporate brand effectively by evaluating them. They, namely multiple stakeholders' reliance, financial value and strategic position, determine whether a corporate brand strategy can add significant value to the corporation and SBUs or give the corporation leverage to move its tangible and intangible assets throughout the organization.

\section{[INSERT FIGURE1]}

\subsection{Multiple stakeholders' reliance}

Stakeholders are all the people (and organizations or groups) that have an interest in a company, and that may influence the company or be influenced by its activities. Freeman (1984) mentioned that stakeholders were any group or individuals who were affected by or could affect the achievement of an organization's objectives. Stakeholders are important to the organization by virtue of their ability to influence it. As a result, their views must be a component of decision-making. However, some stakeholders are more powerful than others. So, the task of management is a balancing act.

Basically, one of the criteria for evaluating the effectiveness of a plan, or strategic plan is satisfaction, resulting in reliance on the part of the stakeholders. And corporate brand strategy must be developed to deliver the highest gains to all stakeholders and corporate publics. A successful organization is responsive to its critical stakeholder needs and meets their expectations. Also, it must assess and understand their needs and expectations continually and anticipate their changeable expectations.

In relation to corporate branding strategy as a corporate level subject, the main difference between product and corporate branding is the target of branding. The product branding target is one consumer or consumer segment with a single message while the target of corporate branding is multiple audiences with a key single message that is meaningful to all, although each constituency may regard the message differently. It is this multiplier effect that gives the corporate branding program its power (Gregory and Wiechmann, 1997). The corporations that use corporate brand strategy distinguish themselves from their competitors and differentiate themselves in the minds of their stakeholders (Balmer, 2004).

Van Riel and Bruggen (2002) presented the SIDEC model that suggests under which conditions SBU managers are willing to support a uniform corporate branding strategy and under which conditions they prefer to use an autonomous branding strategy. Corporate brands focus on building relationships with multiple stakeholder groups in order to create a stable image of corporation products and services.

\subsection{Financial value}

Brands as an intellectual capital are widely considered as an important contributor to business performance and economic growth and ultimately economic performance. Furthermore, brand strategy is a significant factor in the financial success of a corporation. Branding strategy has an impact on a firm's financial performance (Zyglidopoulos et al., 2006; Alessandri and Alessandri, 2004; Olins, 1990). 
Gregory and Wiechmann (1997) pointed out that there were data that linked corporate branding with increased sales, increased market share, increased earnings, and increased stock price. They also presented the "corporate branding index" which is a systematic method of measuring the impact of corporate brand and trade advertising on corporate reputation and financial performance over a specific time period.

Zyglidopoulos et al (2006) measured the financial performance of corporate brand strategy through the use of the average ROA for the financial years of 1996, 1997, and 1998, drawn from Compustat. Their findings indicated the fitness between brand strategy (monolithic approach and branded approach) and business strategy (low cost and differentiation).

Schultz and Schultz (2005), presented three pathway models for measuring brands: 1) customer-based brand matrices consisting of attitudinal data, hierarchy of effects and tracking studies; 2) incremental brand sales consisting of marketplace performance data, marketing mix modeling ROI, and predictive modeling ROCI; 3) branded business value consisting of brand valuation, discounted cash value and brand scorecard.

\subsection{Strategic Positioning}

Basically, branding is about creating a unique position and distinguishing the corporation from its rivals. Schmidt and Ludlow ( 2002) defined positioning as it is normally used in marketing to denote the distinctive market position which a brand has, or wishes to have, in relation to its competition. They presented a holistic approach to positioning. Keller (2000) identified some characteristics for a successful brand which is effectively positioned. And De Chernatony and McDonald (2003) explored the two types of competitive brand advantage: cost-driven and value-added.

Positioning is the differentiation of brand or product according to the target market' perception relative to similar offerings in the given markets. All elements of a company's behavior affect the position in customers' minds. Tadevosyan et el (2008) argued that there was a lake of research about corporate brand positioning, while previous researchers had focused on product brand positioning.

In general, brand positioning refers to consumers' perceptions and insights about a special brand as well as the niche the brand occupies in their mind. Chew (2009) differentiated between strategic positioning, strategic position and positioning strategy since the term 'position' has a variety of meanings in the literature.

Strategic positioning is synonymous with positioning in the literature and is a process of defining and maintaining a distinctive place in the market for organization, operation, and assessing organization position relative to competitors (Zineldin and Bredenlow, 2001). Several authors suggested two approaches to strategic position: internal organization and external target audience (Reddy and Campbell, 1993; Hooley 2001; Fill 2002; Attia 2003). Strategic position of a corporation is the outcome of decisions made at the corporate level and is influenced by the external environment, such as availability of internal resources and core competences, and the expectations of various internal and external stakeholders (Johnson, Scholes and Whittington, 2006). Strategic position also provides direction for operational positioning. However, positioning at the product/brand or operational level involves identifying how the organization's offerings are perceived by its users/consumers relative to other competing products or brands. Additionally, it develops appropriate marketing mix strategies that support their position in the marketplace (Chew, 2009).

Strategic position at the organizational level is a long-term process of developing the organization's overall competitive advantage in the marketplace. It identifies the organization's place in the environment in relation to vision, mission and core competency ( Hooley, 2001; Hamel and Parahalad ,1993). It also requires managers to take deliberate and proactive actions to identify and develop the organization's competitive position based on its operational and experiential dimensions rather than promotional efforts (Kalafaties, Tsogas and Blankson, 2000). In this paper, SBU strategic position, which results from using corporate brand strategy, is a position that every SBU has in the marketplace against its competitive forces. In this paper, SBU strategic position refers to the position held by every SBU against its competitive forces as a result of the use of corporate brand in the marketplace.

\section{METHODOLOGY}

The research was done in two stages. In the first stage, the judgment of specialist experts was utilized to use the Delphi method with respect to objectives and expectations of applying corporate brand strategy in response to the open question "Why do firms apply corporate brand strategy mainly?" The members of the panel consisted of 26 experts who were familiar with strategic management and marketing concepts and also worked at the top level of holding companies by snowball sampling. They suggested several factors that showed objectives and 
expectations of applying corporate brand strategy. Based on these factors, three constructs were identified and used in this paper to design the conceptual model.

The second stage of this research paper was to validate these elements. For this reason, a questionnaire was developed and distributed. Reliability and validity of questionnaire responses according to the final sample consisted of 221 managers of SBUs at top, middle and functional level in 63 firms in food, detergent, hygienic and cosmetic industries in Iran.

Validity of the questionnaire using Cronbach's alpha and reliability based on confirmatory factor analysis are investigated. Since Cronbach's alpha coefficient of all three constructs is more than $70 \%$ and the t-statistics for each factor loading indicators with desired constructs is larger than 1/96, as a result, measuring construct validity has been confirmed.

\section{Measures}

To measure the required data for the research, responses to the multiple choices have been used. (SP) construct with eight indicators, (MSR) construct with eight indicators and (FV) construct with five indicators have been measured. The correlation between the measured parameters, mean and standard deviation are shown in Table 1.

\section{[INSERT TABEL 1]}

Model fitness indicators have supported the appropriately fitting of the model. (GFI=. /90), (CFI=.96), $(\mathrm{NNFI}=.96),(\mathrm{NFI}=.90)$ are all close to 1 , indicating that the model is fit. Also the indices RMSEA and RMR with values close to zero, .044 and .036 respectively, show that the model is fitted to the data.

Correlation coefficient between the (SP) constructs and (MSR) are equal to .45 and the t value is equal to 6.64 in less than .01 is statistically significant. Correlation coefficient between the (SP) constructs and (FV) is equal to .46 and the $\mathrm{t}$ value is equal to 6.22 in less than .01 is also statistically significant. Correlation coefficient between (MSR) constructs and (FV) is equal to .65 and the t value is equal to 10.76 in less than .01 is statistically significant. Correlation coefficient between constructs is shown in Table 2 and Figure 2.

\section{[INSERT TABEL 2]}

\section{[INSERT FIGURE2]}

The survey of second-order factor analysis has shown that the gamma coefficients between the first -order on the second are positive and significant. Standardized path coefficient between (SP) and (ECBC) is equal to .56 and its $t$ value is equal to 5.35 in less than .01 is statistically significant. Standardized path coefficient between (MSR) and (ECBC) is equal to .8 0 and its $t$ value is equal to 5.85 in less than .01 is statistically significant. Standardized path coefficient (FV) and (ECBC) is equal to .81 and its t value is equal to 6.01 in less than .01 is statistically significant. The results of standardized path coefficient between constructs of the model in Table 3 and Figure 3 are shown.

$$
\text { [INSERT TABEL 3] }
$$

\section{[INSERT FIGURE 3]}

\section{CONCLUSION}

The results of the model showed that the factors determining the effectiveness of corporate brand strategy are related to each constructs in the conceptual model. These findings indicate that we can measure these dimensions to assess the effectiveness of corporate branding strategy. The effectiveness of corporate branding strategy displays itself if the corporation and SBUs are leading up to their intended results. To determine the effectiveness of corporate branding strategy, the paper suggests that companies should assess both corporation and SBU performance as against the business's tangible and intangible criteria such as multiple stakeholders' reliance, financial value and strategic position.

Reliance of multiple stakeholders results from their satisfaction which impacts on the corporation and which has different value and weight. The customers, SBU managers, investors, suppliers, partners, employees, SBU employees, regulators, media, and local community organizations are multiple stakeholders that influence the performance of corporate branding strategy and have different effects on CEO decisions.. After identifying stakeholders and determining their importance, the next step is to delineate some criteria to assess their reliance as follows: 
- Customers: Customer perception of corporate brand, willingness to pay, loyalty etc.

- SBU managers: Willingness to use corporate brand, commitment etc.

- Employees: Commitment, loyalty, support of corporate mission and vision, number of job applications received, employee retention rate etc.

- Suppliers: Willingness to interact with the organization etc.

- Partners: Satisfied with the contract etc.

- Media: Presence, relation with the organization etc.

- SBU employees: Commitment to corporation, number of job applications received, employee satisfaction rate, etc.

The cumulative effect of these groups' satisfaction or the average weight of these variables displays one of the impact factors on the effectiveness of corporate branding strategy powerfully and directly.

SBUs' strategic position results from the corporate brand strategy, and causes SBUs to move in the competitive market without dependency and threat. However, SBUs strategic position depends on several factors such as their special industry, market share, profitability, kind of products and services, sales strategies, SBU performance and capabilities and so on, but the paper suggests assessing three factors for SBU's strategic position: the sustainability of SBUs' strategic position over time, the parent company's reputation, and the corporate image. These factors show SBUs' strategic position in the marketplace. They can help managers to investigate the effect of the corporate brand strategy.

\section{SUGGESTIONS FOR FUTURE RESEARCH}

There is a need for future research to show how we can assess the financial value result of applying a corporate brand strategy based on the model and how we can measure corporate brand strategy impacts on SBUs' strategic position.

\section{REFERENCES}

1. Aaker, D.A. (1996). Building Strong Brand. New York: The Free Press.

2. Aaker, D.A. (2004). Leveraging the Corporate Brand. California Management Review 46 (3): 1-18.

3. Aaker, D.A. \& Joachimsthaler, E. (2000). Brand Leadership. New York: The Free Press.

4. Alessandri, S.W. \& Alessandri, T. (2004). Prompting and Protecting Corporate Identity: The Importance of Organizational and Industry Context. Corporate Reputation Review 7(3): 252-268.

5. Attia, S. (2003). Achieving sustainable competitive advantage positioning: the role of resources within environmental constrains. Unpublished thesis, Aston Business School, Birminghham,UK.

6. Balmer, J.M.T. (2001). corporate identity, corporate branding and corporate marketing - seeing through the fog. European Journal of Marketing 35 (3-4): 248.

7. Balmer, J.M.T. (2004). The Corporate Branding Triumvarite: Values, Promise and Behavior? Working Paper Series No 04/31.

8. Balmer, J.M.T. and Gray, E.R. (2003). corporate brands: What are they? What of them? European Journal of Marketing 37 (7-8): 972-997.

9. Goold, M,. Campbell, A. \& Alexander, M. (1995). The value of the parent company. California Management review 38 (1): 79-97.

10. Chew, C. (2009). Strategic Positioning in Voluntary and Charitable Organizations. New York: Routledge.

11. DeChernatony, L. \& McDonal, M. (2003). Creating Powerful Brands. Elsevier/ButterworthHeinemann, Oxford.

12. Eisenhardt, K.M. \& Zbaracki, M.J. (1992). Strategic decision making. Strategic Management Journal, 13: $17-37$.

13. Fill, C. (2002). Marketing Communications: Contexts, Strategies and Applications, New Jersey: Pearson Education.

14. Freeman, R.E. (1984). Strategic Management: A Stakeholders Approach. Boston: Pitman.

15. Gregory, J.R. \& Wiechmann, J.G. (1997). Leveraging the Corporate Brand. NTC Business Books. Lincolnwood, USA.

16. Hamel, G. \& parahalad, C.K. (1993). Strategy as stretch and leverage. Harvard Business Review 71(2):75-84.

17. Hatch, M.J. \& Schultz, M. (2003). Bringing the corporation into corporate into corporate branding. European Journal of Marketing 37 (7-8): 1041-1046.

18. Hatch, M.J. \& Schultz, M. (2008). Taking Brand Initiative: How Companies Can Align Strategy, Culture, and Identity through Corporate Branding? Jossey-Bass: 1-149.

19. Hatch, M.J. \& Schultz, M. (2001). Are the Strategic Stars Aligned for Your Corporate Brand. Harvard Business Review 79(2): 128-134. 
20. Holley, G.J. (2001). Positioning. In Encyclopedia of Marketing, Baker, M (ed), London, Thomson Learning, 309-15.

21. Ind, N. (1997). The corporate Brand. London: Macmillan business.

22. Johnson, G., Scholes, K. \& Whittington, R. (2006). Exploring Corporate Strategy (7th edn). PrenticeHall, England.

23. Kalafaties, S.P., Tsogas, M.H. \& Blankson, C. (2000). Positioning strategies in business markets. Journal of Business \& Industrial Marketing 15(6): 416 - 437.

24. Kapferer, J.N. (2008). The New Strategic Brand Management, Kogan Page, London and Philadelphia.

25. Keller, K.L. (2000). Building and managing corporate brand equity. Schultz M, Hatch MJ, Larsen MH (Eds) The expressive organization, Oxford University Press, Oxford: 115-37.

26. Keller, K.L. \& Aaker, D.A. (1998). The impact of corporate marketing on a company's brand extensions. Corporate Reputation Review 1:356-378.

27. Laforet, S. \& Saunders, J. (1999). Managing Brand Portfolios: Why the Leaders do What They Do. Journal of Advertising Research 39(1): 51-66.

28. Muzellec, L. \& Lambkin, M.C. (2009). corporate branding and brand architecture: a conceptual framework. Marketing Theory 9 (1): 39-54.

29. Olins, W. (1990). The Wolff Olins Guide to Corporate Identity. London, The Design Council.

30. Ormeno, M. (2007). Managing Corporate Brands; A new approach to corporate communication. GWV Fachverlage GmbH,Wiesbaden: 11-30.

31. Reddy, A.C. \& Campbell, D.P. (1993) Positioning Hospitals: A Model for Regional Hospitals. Journal of Healthcare Marketing 13(1): 40-4.

32. Sadler, P. (2003) Strategic Management. Kogan Page Limited, UK.

33. Schmidt, K. \& Ludlow, C. (2002) Inclusive Branding: The why and how of a holistic approach to brands. Basingstoke, Palgrave Macmillan.

34. Schultz, H.F. \& Schultz, D.E. (2005) Measuring Brand Value. in Kellogg on branding. New Jersey: John Wiley \& Sons, $244-271$.

35. Tadevosyan, L., Mazzucato, L. \& Kos-Hansen, O. (2008). Corporate Brand Positioning. Master Thesis, Lund University. Sweden.

36. Van Riel, C.B.M \& Van Bruggen, G.H. (2002). Incorporating Business Unit Managers' perspectives in corporate-branding strategy decision making. Corporate Reputation Review 5(2-3)241-251.

37. Varadarajan, R., DeFanti, M.P. \& Busch, P.S. (2006). Brand Portfolio, Corporate Image, and Reputation: Managing Brand Deletion. Journal of the Academy of Marketing Science 34(2): 195-205.

38. Wilson, D. (2003). Strategy as decision making. In S. Cummings, \& D. Wilson (Eds.), Images of strategy: 383-410. Oxford: Blackwell.

39. Zineldin, M. \& Bredenlow, T. (2001). Performance measurement and management control positioning strategies, quality and productivity: A case study of a Swedish bank. Managerial Auditing Journal 6(9):484-89

40. Zyglidopoulos, S.C., Alessandri, S.W. \& Alessandri, T.M. (2006). Exploring the Moderators on the Branding Strategy- Financial Performance Relationship. Judge Business School, University of Cambridge.

Figure 1: The research conceptual model

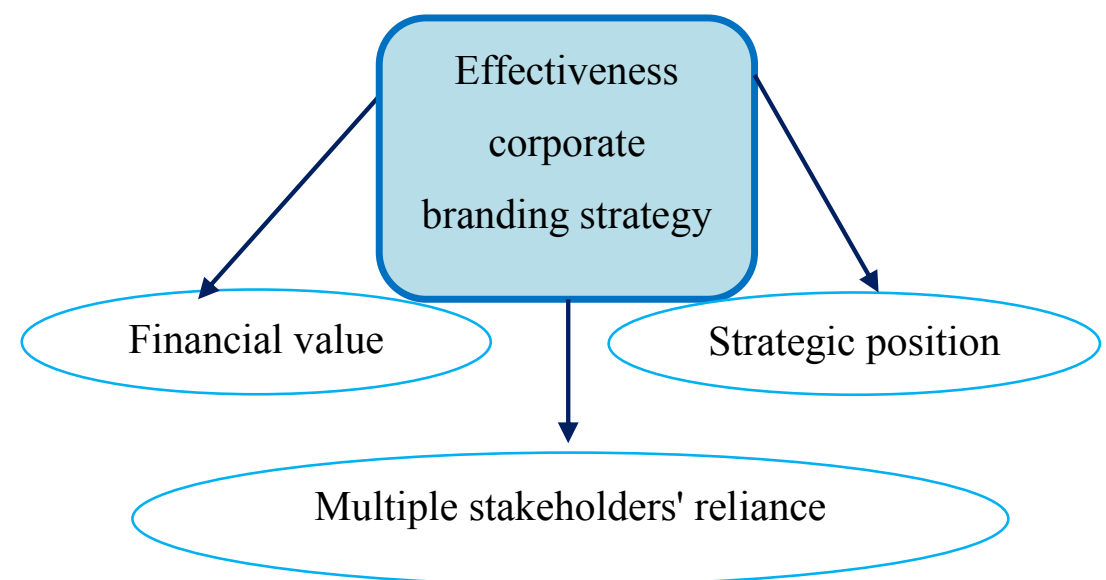


Table 1: The measured mean, standard deviation parameters and the correlation between them

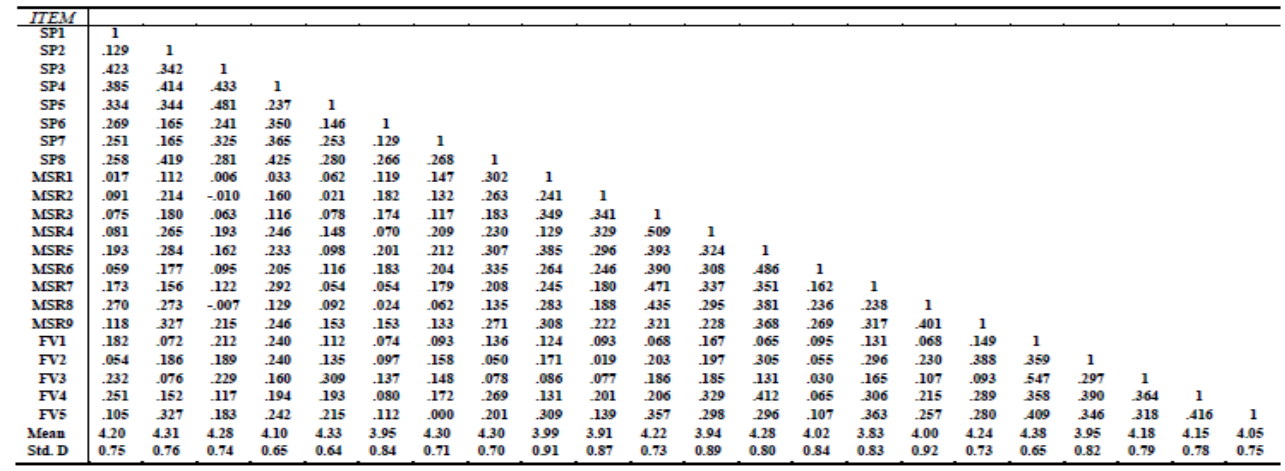

Table 2: Results of validity and reliability indices

\begin{tabular}{|c|c|c|c|c|c|}
\hline$\alpha^{2}$ & $\mathbf{R}^{2}$ & t-value & $\begin{array}{l}\text { Factor } \\
\text { loading }\end{array}$ & Items & Constructs \\
\hline \multirow{9}{*}{0.768} & & & & & Strategic position \\
\hline & 0.30 & 8.09 & 0.54 & Create a unique position in the & SP1 \\
\hline & 0.35 & 8.64 & 0.59 & Employ quality workforce & SP2 \\
\hline & 0.37 & 9.20 & 0.61 & Positive image & SP3 \\
\hline & 0.52 & 11.17 & 0.72 & Create a unique identity for the & SP4 \\
\hline & 0.27 & 7.40 & 0.52 & Create reputation for the & SP5 \\
\hline & 0.16 & 5.64 & 0.40 & Acceptance of new products & SP6 \\
\hline & 0.20 & 6.47 & 0.45 & Better to introduce new & SP7 \\
\hline & 0.35 & 9.30 & 0.59 & Using synergy & SP8 \\
\hline \multirow{10}{*}{.798} & & & & & Multiple stakeholders' reliance \\
\hline & 0.24 & 7.18 & 0.49 & Better communication & MSR1 \\
\hline & 0.18 & 6.14 & 0.43 & A key motivation for & MSR2 \\
\hline & 0.51 & 11.24 & 0.71 & keep key stakeholders & MSR3 \\
\hline & 0.37 & 9.09 & 0.61 & Increase staff confidence & MSR4 \\
\hline & 0.32 & 8.54 & 0.57 & Increase customer confidence & MSR5 \\
\hline & 0.21 & 6.54 & 0.45 & Increase customer loyalty & MSR6 \\
\hline & 0.32 & 8.47 & 0.57 & Increase satisfaction & MSR7 \\
\hline & 0.27 & 8.08 & 0.52 & Increase the confidence of & MSR8 \\
\hline & 0.28 & 7.81 & 0.53 & Recruitment well-known & MSR9 \\
\hline \multirow{6}{*}{.750} & & & & & Financial value \\
\hline & 0.29 & 7.53 & 0.54 & Unique selling & FV1 \\
\hline & 0.30 & 7.80 & 0.55 & The advantage of using the & FV2 \\
\hline & 0.22 & 6.55 & 0.47 & Reduced costs & FV3 \\
\hline & 0.38 & 8.96 & 0.61 & Increase Profitability & FV4 \\
\hline & 0.50 & 10.47 & 0.71 & Increasing investment & FV5 \\
\hline
\end{tabular}

\footnotetext{
- Standardized Solution

2 - Cronbach's Alpha
} 
Figure 2: The measurement of model based on standardized parameters and $\mathrm{T}$ index

Correlation Matrix of ETA and KSI

$\begin{array}{rrrrr} & \text { SP } & \text { MSR } & \text { FV } & \text { ECBC } \\ & -.- & \cdots-. & \ldots .-1 . & \\ \text { SP } & 1.00 & & & \\ \text { MSR } & 0.45 & 1.00 & & \\ \text { FV } & 0.46 & 0.65 & 1.00 & \\ \text { ECBC } & 0.56 & 0.80 & 0.81 & 1.00\end{array}$

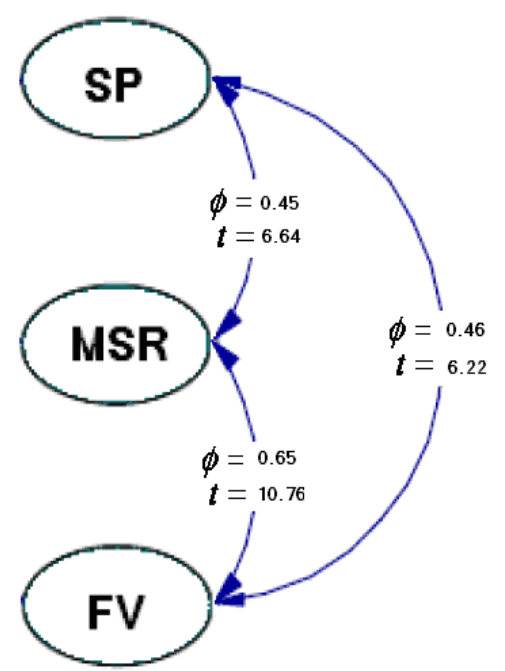

Table 3: Results of structural equation related to the effectiveness of corporate branding strategy

\begin{tabular}{|c|c|c|c|c|}
\hline \multicolumn{2}{|c|}{ Structural Equations } & \multicolumn{2}{c|}{ Error rate } & $\left(\mathrm{R}^{2}\right)$ \\
\hline $\mathrm{SP}=0.23 * \mathrm{ECBC}$ & $\mathrm{T}=5.35$ & 0.12 & $\mathrm{~T}=3.82$ & 0.32 \\
\hline $\mathrm{MSR}=0.36 * \mathrm{ECBC}$ & $\mathrm{T}=5.80$ & 0.069 & $\mathrm{~T}=2.33$ & 0.65 \\
\hline $\mathrm{FV}=0.29 * \mathrm{ECBC}$ & $\mathrm{T}=6.01$ & 0.042 & $\mathrm{~T}=2.18$ & 0.66 \\
& & & & \\
\hline
\end{tabular}

Figure 3: Graph model of the structural equation based on standardized parameters and the index T

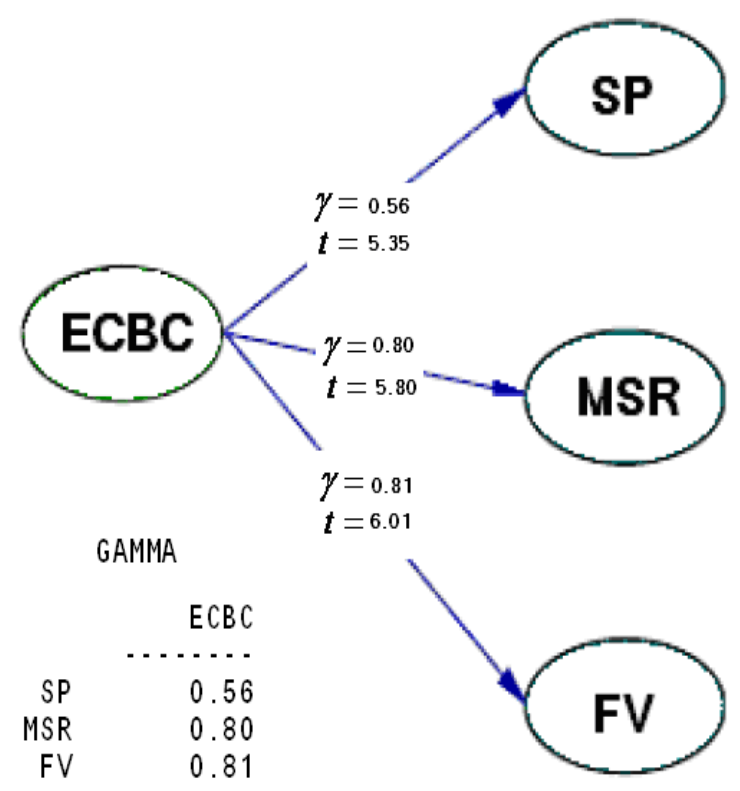

